\title{
Impact of the Discipline of Work and the Working Environment Against the Success of the Educator
}

\author{
Amrullah $^{1 *)}$, Edi Harapan ${ }^{2}$, Tahrun $^{2}$ \\ ${ }^{1}$ SD Negeri Cinta Karya, Indonesia \\ ${ }^{2}$ Universitas PGRI Palembang, Indonesia \\ *Corresponding author. Email: madaniamrullah27@gmail.com
}

\begin{abstract}
The intention of the whole project is to discover and analyze the impact of work discipline, work environment on the performance of teachers in SD Negeri at Plakat Tinggi District. This mode of analysis shall be quantified in the explanatory statement. The sample in the research comprised of 59 respondents using the sampling procedure in the form of a survey (questionnaire). The findings indicate that: 1) there is a serious impact of work discipline on the quality of teachers; 2) there is a serious influence of the work environment on the performance of teachers; 3) there is a noticeable impact between work discipline and the work environment on the quality of teachers.
\end{abstract}

Keywords: Discipline of Work, Working Environment, Success of the Educator

\section{INTRODUCTION}

The whole analysis stemmed from the findings of observations made by researchers on 23 September 2019 from fellow teachers around the researcher's work climate, which revealed that there were still teachers who were less excited about teaching, who did not make learning resources, who left the classroom that was their responsibility, and who were less creative in the implementation of learning. And if a teacher is meant to be a role model for students. The teaching spirit of the teacher would have an effect on the students' abilities. Unfortunately, some teachers are simply undermotivated so that they do not fulfill their duties optimally. That illustrates that the success of teachers in the study design is still missing.

Many factors have an effect on efficiency, including environmental performance, management behavior, work design, performance evaluation, feedback and pay administration. The performance of a person is highly influenced by the potential, motivation and opportunity factors [1]. Teacher performance can be demonstrated by the ability of the teacher to master the requisite competencies, i.e. pedagogical competence, personality competence, social competence and professional competence Law No. 14 of 2005 [2].
Its reality that academics had identified, given previous scientific publications by Alhusaini, et al, that teaching output in many schools is still considered inadequate due to a lack of teaching discipline [3]. This is confirmed on the basis of studies by Damayani, et al. In her study, she clarified that the output of teachers is still an issue that requires attention. One of the measures is lack of discipline, and teacher control of subjects and teaching methods is not optimum. As a result, the professional productivity, quality and competence of teachers are also considered not to meet the expectations. The teacher's success is geared towards mastering theory and memorization, making it difficult for students to improve their skills optimally and completely as they wish [4].

Previous research by Fransiska, et al, has shown that the performance of the teacher would be strong if the leadership style of the principal is successful and if the teacher also has a high work discipline. Teacher success can be optimized with the Principal's style of leadership that can motivate teachers to provide high school discipline so that they can always display their best performance in achieving school goals. The outcomes of this survey therefore support the view that the relationship between the innovative leadership of SD director Negeri Rambang Kapak Tengah and the teaching work discipline has a strong great impact on the success of teachers [5]. 
Analysis by Kartini et al. The low performance of school teachers is affected by a number of factors, including competence, work morale, work discipline, job satisfaction, the teaching organization, the leadership of school principals, and the nature of government policies on education [6]. This is consistent with Kasmir's view that the performance of teachers is affected by a variety of factors, including: work environment, organizational culture, leadership, work motivation, work discipline, pay, job satisfaction and other factors. Teacher output would be optimal if it is incorporated with the school components, whether they are the principal or students [7]. As per Suharsaputra, the role of teachers is very dominant in the transformation of students into skilled human beings, without reducing or removing other roles and functions, and the performance of teachers as educators is one of the factors that plays an important role in the success of education [8].

In comparison to motivating factors for work, the success of teachers is often affected by the discipline of work. Labor discipline influences also play an important role in increasing the effectiveness of teaching teachers. Strong work discipline is required to achieve the planned objectives. Performance refers to the following characteristics or metrics: performance in a company may be said to improve if it meets indicators such as: consistency of the results of work, timeliness, initiative, expertise and good communication.

Leadership requires three meanings, namely effort, the ability to manage a company, and an authority that makes someone deemed capable of leading. Institutional leaders must be able to play an active role and be able to position themselves strategically in the governance of the organization. Success and effectiveness of the school principal can be pursued by respecting one another, working together and gaining information of the actions of employees [9];[10];[11].

However, power comes not only from the chief, but may also come from the discipline of the teacher's work. This means that the success of the leader is not only due to his ability to lead, but is also determined by how much discipline the instructor works to promote the success of the leader. School principal as chief has the power and policies to enhance the quality of education [10]. In addition, Hasibuan clarified, discipline is the knowledge or ability of a person to abide by all the laws and social norms that apply [12].

Work discipline has several objectives Permatasari et al, which note that the objectives of work discipline are: 1) to ensure that teacher conduct is compatible with school rules; 2) to promote or sustain respect and mutual trust; 3) disciplinary action may also enable teachers to become more productive; and 4) successful disciplinary action can motivate individual teachers to enhance their work performance or performance. It can be concluded that the lack of discipline on the part of the teacher in carrying out assignments, such as regular late school arrivals, results in a low student quality indifference [13].

In comparison to the fact that the issue of job discipline is frequently ignored by teachers, this can be seen from a variety of examples, for example: teachers come to school late, teachers are not in school during working hours, work is delayed, teachers leave early, etc. The most critical thing for certain teachers is to fill up the attendance list. This will have an indirect effect on the work of Enni et al [14]. Researchers in the field have also found something similar from a number of state elementary schools in the Rambang Kapak Tengah District, which have found that the work discipline problem can still be said to be low. That's also attributable to the fact that there are still teachers who come to school late, leave school before going home for a variety of reasons, miss work, do not schedule lessons. If this situation is left to drag on, it is feared that the planned goals for schooling will not be met, resulting in poor quality of school education. Education is essentially an effort to humanize humans [15].

Based from the above explanation, visionary leadership and teaching discipline play an important role in enhancing teacher performance. If the teaching output of teachers is well carried out, the standard of public primary school education in the Rambang Kapak Tengah District can be achieved. It is therefore necessary to carry out more research. Considering the context of the above, the researcher will design a survey entitled " Impact of the Discipline of Work and the Working Environment Against the Success of the Educator, in SD Negeri at Plakat Tinggi District"

\section{METHODS}

Methodology is a deciding factor in the merits of the writing of scientific papers [16]. So according Sukmadinata, the research method is a set of methods or practices for carrying out research based on basic assumptions, philosophic and ideological beliefs, questions and issues at hand. The research approach has a particular design for research. This research approach is quantitative research by explaining the results of the research [17].

Statistical method is based on the theory of positivism, which emphasizes numerical data and is experimentally studied. The total number of respondents is the SD Negeri in the Plakat Tinggi District, which is sampled in this study using objective sampling, that is to say, teachers who are used as research samples are teachers in each primary school with a total of 59 teachers. Techniques are required for the collection of data, both techniques for the provision of data and techniques for the classification of data that have been 
collected. The same argument has also been made by Sugiyono that the questionnaire is the widely used program for statistical, while the data analysis technique is the method used to carrying out the method chosen, which uses survey questionnaire and documentation [18]. The data collection method included in this study clear correlation and multiple regression data analysis

techniques with the aid of the SPSS For Windows Version 22 software. The implementation process of the research included: (1) a descriptive analysis, (2) a test of the analysis criteria and (3) a test of the hypothesis.

\section{RESULTS AND DISCUSSION}

Table 1. Results of Multiple Correlation Statistical Analysis and Coefficient of Determination

\begin{tabular}{|c|c|c|c|c|}
\hline \multicolumn{5}{|c|}{ Model Summary ${ }^{b}$} \\
\hline Model & $\mathrm{R}$ & R Square & Adjusted R Square & Std. Error of the Estimate \\
\hline 1 & $.711^{\mathrm{a}}$ & .506 & .488 & 10.756 \\
\hline \multicolumn{5}{|c|}{ a. Predictors: (Constant), Working Environment $\left(\mathrm{X}_{2}\right)$, Discipline of Work $\left(\mathrm{X}_{1}\right)$} \\
\hline \multicolumn{5}{|c|}{ b. Dependent Variable: Success of the Educator (Y) } \\
\hline
\end{tabular}

Table 2. Results of the F Test Analysis

\begin{tabular}{|c|c|c|c|c|c|c|}
\hline \multicolumn{7}{|c|}{ ANOVA ${ }^{b}$} \\
\hline \multicolumn{2}{|c|}{ Model } & Sum of Squares & df & Mean Square & $\mathrm{F}$ & Sig. \\
\hline \multirow[t]{3}{*}{1} & Regression & 6635.335 & 2 & 3317.668 & 28.679 & $.000^{\mathrm{a}}$ \\
\hline & Residual & 6478.190 & 56 & 115.682 & & \\
\hline & Total & 13113.525 & 58 & & & \\
\hline \multicolumn{7}{|c|}{ a. Predictors: (Constant), Working Environment $\left(\mathrm{X}_{2}\right)$, Discipline of Work $\left(\mathrm{X}_{1}\right)$} \\
\hline \multicolumn{7}{|c|}{ b. Dependent Variable: Success of the Educator (Y) } \\
\hline
\end{tabular}

Table 3. Results of $t$ test analysis

\begin{tabular}{|c|c|c|c|c|c|c|}
\hline \multicolumn{7}{|c|}{ Coefficients $^{\mathbf{a}}$} \\
\hline \multirow{2}{*}{\multicolumn{2}{|c|}{ Model }} & \multicolumn{2}{|c|}{$\begin{array}{l}\text { Unstandardized } \\
\text { Coefficients }\end{array}$} & \multicolumn{3}{|c|}{$\begin{array}{c}\text { Standardized } \\
\text { Coefficients }\end{array}$} \\
\hline & & $\mathrm{B}$ & Std. Error & Beta & $\mathrm{t}$ & Sig. \\
\hline \multirow[t]{3}{*}{1} & (Constant) & 22.719 & 9.692 & & 2.344 & .023 \\
\hline & $\begin{array}{l}\text { Discipline of Work } \\
\left(\mathrm{X}_{1}\right)\end{array}$ & .352 & .146 & .317 & 2.417 & .019 \\
\hline & $\begin{array}{l}\text { Working } \\
\text { Environment }\left(\mathrm{X}_{2}\right) \text {, }\end{array}$ & .429 & .124 & .453 & 3.462 & .001 \\
\hline
\end{tabular}

After testing the data analysis criteria, namely the normality test and the homogeneity test, the hypothesis test was continued. After the data are declared to have met the criteria to be checked, the hypothesis is tested using the t-test and the F-test to assess the effect on the variables to be tested in part and at the same time.

Concluded on the basis of the review of empirical data using version 22 of the SPSS program. Before the test is carried out, the data standards were first tested, namely the validity test and the reliability test. The data validity test was carried out using the validation test carried out with the validator, namely the PGRI Palembang University lecturer. Then proceed to verify the validity of the analysis using the SPSS software version 22 estimate. The results of the research validation measurement for the job discipline variable note that they are all correct for further testing of the statement objects. The results of the study validity measurement for the work environment variables note that all of them are correct so that the statement items can be further checked. The results of the validity analysis measurement for the teacher output variables note that all of them are correct so that the statement items can be further checked. The pre-requisite data test would then be continued for the reliability test. After measurement using the SPSS version 22 program, it is known that the work discipline variable has a value greater than the $r$ table, that the work environment variable is greater than the $r$ table, and that the teacher output variable has a value greater than the $r$ table, so that it can be concluded that all the research variables are considered accurate. 


\section{CONCLUSION}

Based on the findings of the research that has been performed, it can be concluded that the job discipline affects the performance of the instructor on the basis of the results of the t-test study. This shows that there is an influence of the work discipline on the success of SD Negeri in the Plakat Tinggi District, which replied to the first hypothesis. The job environment affects the performance of the instructor on the basis of the effects of the t-test examination. This indicates that there is an effect of the working atmosphere on the output of teachers in SD Negeri in the Plakat Tinggi District, according to the second hypothesis.

\section{AUTHORS' CONTRIBUTION}

Amrullah: designed and performed experiments and analysed data. Edi Harapan and Tahrun: proofing.

\section{ACKNOWLEDGMENTS}

Thank you to your family and colleagues, the Chancellor of the PGRI Palembang University, the Director of the PGRI Palembang University Postgraduate Program, the Chair of the PGRI Palembang University Education Management Masters Program and the supervisors who have contributed to the completion of this study journal.

\section{REFERENCES}

[1] Robbins., \& Judge. (2012). Perilaku Organisasi (Organizational Behavior) Buku 1 [Organizational Behavior. Book 1. Edition]. Edisi. Jakarta: Salemba Empat.

[2] Undang-Undang Nomor 14 Tahun 2005 Tentang Guru dan Dosen [Law No. 14 of 2005 on Teachers and Lecturers].

[3] Alhusaini. A, Kristiawan. M, dan Eddy. S (2020). Pengaruh Motivasi Kerja dan Disiplin Kerja Terhadap Kinerja Guru [The Effect of Work Motivation and Work Discipline on Teacher Performance]. Jurnal Pendidikan Tembusai. Volume 4 Nomor 3 Tahun 2020. ISSN: 2614-3097.

[4] Damayani, Titin., Arafat, Y. dan Eddy, S. (2020). Pengaruh Kepemimpinan Kepala Sekolah dan Motivasi Kerja terhadap Kinerja Guru [The Influence of Principal Leadership and Work Motivation on Teacher Performance]. Journal of Innovation in Teaching and Instructional Media Vol. 1 No. 1, Page:46-57.

[5] Fransiska.W, Harapan.E \& Tahrun (2020). Pengaruh Kepemimpinan Visioner Kepala Sekolah dan Disiplin Guru terhadap Kinerja Guru Sekolah Dasar [The Effect of Principal Visionary
Leadership and Teacher Discipline on Primary School Teacher Performance]. Journal of Education Research, 1(3), 2020, Pages 308-316.

[6] Kartini, Ahmad. S, Eddy. \& S (2020). Pengaruh Gaya Kepemimpinan Kepala Sekolah dan Komunikasi Interpersonal Terhadap Kinerja Guru [The Effect of Principal Leadership Style and Interpersonal Communication on Teacher Performance]. Journal of Education Research, 1(3), 2020, Pages 290-294.

[7] Kasmir. (2018). Manajemen Sumber Daya Manusia [Human Resource Management]. Depok: Rajawali Pers

[8] Suharsaputra. (2016). Kepemimpinan Inovasi Pendidikan: Mengembangkan Spirit Enterpreneurship Menuju [Learning School Innovation Leadership: Developing a Spirit of Entrepreneurship Towards a Learning School]. Bandung: PT Refika Aditama.Educational

[9] Kristiawan, M., \& Asvio, N. (2018). Pengelolaan Administrasi Madrasah Tsanawiyah Negeri Dalam Meningkatkan Kualitas Pendidikan Madrasah [Administrative Management of State Madrasah Tsanawiyah to Improve the Quality of Madrasah Education]. Kelola: Jurnal Manajemen Pendidikan, 5(1), 86-95.

[10] Tobari., Kristiawan, M. \& Asvio, N. (2018). The Strategy of Headmaster on Upgrading Educational Quality in Asean Economic Community (AEC) Era. International Journal of Scientific \& Technology Research 7 (4).

[11] Rahmadoni, J. (2018). Isu Global Manajemen Pembiayaan Pendidikan di SD Indonesian Creative School Pekanbaru [Global Issues of Education Financing Management at SD Indonesian Creative School Pekanbaru]. Jurnal Manajemen, Kepemimpinan dan Supervisi Pendidikan 3(2), Juli-Desember.

[12] Hasibuan, M. (2013). Manajemen Sumber Daya Manusia [Human Resource Management]. Jakarta: Bumi Aksara.

[13] Permatasari, Y. M. (2015). Pengaruh Disiplin Kerja dan Motivasi Kerja Terhadap Prestasi Kerja Karyawan [The Effect of Work Discipline and Work Motivation on Employee Performance]. Jurnal Administrasi Bisnis.

[14] Enni., Djasmi, S., \& Sowiyah. (2013). Pengaruh Disiplin Kerja dan Kepemimpinan Kepala Sekolah terhadap Kinerja Guru Sekolah Dasar Negeri Kecamatan Abung Tinggi Kabupaten Lampung Utara [The Effect of Work Discipline and Principal 
Leadership on the Performance of State Elementary School Teachers in Abung Tinggi District, North Lampung Regency]. Jurnal Manajemen Mutu Pendidikan (JMMP). Vol.1, Nomor 1, (2013).

[15] Wandasari, Y., Kristiawan, M., \& Arafat, Y. (2019). Policy Evaluation of School's Literacy Movement on Improving Discipline of State High School Students. International Journal of Scientific \& Technology Research 8(4).

[16] Muttaqin, K., \& Rahmadoni, J. (2020). Analysis and Design of File Security System AES (Advanced Encryption Standard) Cryptography Based. Journal of Applied Engineering and Technological Science (JAETS), 1(2), 113-123. https://doi.org/10.37385/jaets.v1i2.78.

[17] Sukmadinata, N. S. (2015). Metode Penelitian Pendidikan [Educational Research Methods]. Bandung: Remaja Rosdakarya.

[18] Sugiyono. (2018). Metode Penelitian Kuantitatif [Quantitative Research Methods]. Bandung: Alfabeta. 